\title{
SOBRE O POPULISMO NO BRASIL ${ }^{1}$
}

Marilena Chavi²

\section{A invenção democrática}

Com a ideia de invenção democrática, Claude Lefort recriou o conceito moderno de democracia, retomando num contexto novo a ideia de Moses Finley de invenção da política, para indicar uma ação que se realiza sem o apoio de modelos, e, no caso de Lefort, para marcar a recusa de fundamentos externos ao social. Para pensar a experiência política do presente, escreve ele, é preciso afastar, de um lado, a redução marxista da política à condição de superestrutura, e, de outro, a concepção liberal da democracia como regime político da lei e da ordem para assegurar liberdades individuais; e, não menos importante, também afastar as ciências sociais, particularmente a sociologia e a ciência política, que buscam seu objeto a partir da construção ou delimitação do "fato político", considerado um fato particular ao lado de outros fatos sociais particulares (econômico, jurídico, científico, estético, ou simplesmente social, isto é, como modo de relação entre grupos e classes).

Une telle perspective suppose qu'on se donne en sous-main la référence à l'espace dénommé société. Celle-ci, on prétend l’inventorier ou la reconstruire, en posant des termes, en les articulant, en forgeant des systemes particuliers de relations, voire en les combinant dans un systeme global, comme si l'observation ou la construction ne dérivait pas d'une expérience de la vie sociale, à la fois primordiale et singulierement façonnée par notre insertion dans un cadre historiquement et politiquement déterminé. Or, observons aussitôt une conséquence de cette fiction: les sociétés démocratiques modernes se caractérisent, entre autres, par la délimitation d'une sphère d'institutions, de relations, d'activités qui apparait comme politique, distincte d'autres sphères qui apparaissent comme économique, juridique, etc. Politologues et sociologues trouvent dans ce

\footnotetext{
${ }^{1}$ Dossiê Claude Lefort: esse texto é parte do dossiê publicado a partir das comunicações realizadas no Colóquio Internacional Claude Lefort: a invenção democrática hoje, realizado na Universidade de São Paulo entre os dias 13 e 16 de outubro de 2015.

2 Professora Emérita da Faculdade de Filosofia, Letras e Ciências Humanas da Universidade de São Paulo (FFLCH-USP).
} 
mode d'apparaître du politique la condition de la définition de leur objet et de leur démarche de connaissance, sans interroger la forme de société dans laquelle se présente et se voit légitimé le clivage de divers secteurs de la réalité. ${ }^{3 *}$

A atitude da sociologia e da ciência política nasce de uma vontade de objetivação e do esquecimento de que não existem elementos ou estruturas elementares, nem relações sociais, nem determinações econômicas e técnicas pré-existentes ao espaço social - não há dimensões do espaço social antes da formação social. Essa atitude as

prive de penser une expérience qui s'engendre et s'ordonne en raison d'une conception implicite des rapports des hommes entre eux et d'une conception de leurs rapports avec le monde. Elle lui interdit de penser ce qui est pensé dans toute société et lui donne son statut de société humaine: la différence entre la légitimité et l'illégitimité, entre la vérité et le mensonge, l'authenticité et l'imposture, la recherche de la puissance ou de l'intérêt privé et la recherche du bien commun. .** $^{4 *}$

É preciso, ao contrário, interrogar "a forma da sociedade na qual se apresenta e se legitima a clivagem de diversos setores da realidade" e o conjunto de ideias e valores por ela instituídos. Isto significa que a determinação econômica assim como o conjunto das instituições é posta pela forma da sociedade. Não há uma ordem e uma determinação pré-

${ }^{3}$ LEFORT, C. "La question de la démocratie". Essais sur le politique. XIX et XX siècles. Paris: Seuil, 1986, p. 19. * Uma tal perspectiva supõe que se dê como pano de fundo a referência ao espaço denominado sociedade. Quanto a esta, pretende-se inventariá-la ou reconstruí-la ao propor termos, ao articulá-los, ao forjar sistemas particulares de relações, mesmo ao combiná-los num sistema global, como se a observação ou a construção não derivasse de uma experiência da vida social, ao mesmo tempo primordial e singularmente armada por nossa inserção num quadro histórica e politicamente determinado. Ora, observamos tão logo uma consequência desta ficção: as sociedades democráticas modernas se caracterizam, entre outras coisas, pela delimitação de uma esfera de instituições, de relações, de atividades que aparece como política, distinta de outras esferas que aparecem como econômica, jurídica, etc. Politólogos e sociólogos encontram neste modo de aparecer do político a condição da definição de seu objeto e de seu percurso de conhecimento, sem questionar a forma de sociedade na qual se apresenta e se vê legitimada a clivagem de diversos setores da realidade.] (Tradução dos editores)

${ }^{4}$ Ibidem.

** [priva de pensar uma experiência que se engendre e se ordene em razão de uma concepção implícita das relações dos homens entre si e de uma concepção de suas relações com o mundo. Ela lhe impede de pensar o que é pensado em toda sociedade e lhe dá o estatuto de sociedade humana: a diferença entre a legitimidade e a ilegitimidade, entre a verdade e a mentira, a autenticidade e a impostura, a busca pelo poder ou pelo interesse privado e a busca pelo bem comum.] (Tradução dos editores) 
existentes ao social que lhe dariam forma e sentido, mas, ao contrário, é a instituição do social que determina as formas da sociabilidade desde a economia até o exercício do governo. Por esse motivo, a democracia não é um regime político, mas uma formação social. Donde a expressão introduzida por Lefort: sociedade democrática.

A sociedade democrática moderna nasce com a desincorporação do poder, isto é, da imagem do poder encarnado no corpo místico do governante, que detém a lei e o saber, e de cuja vontade nasceria o próprio social, isto é, a democracia moderna nasce quando se apaga a imagem da transcendência do fundamento: nem a Natureza, nem a Razão nem Deus podem oferecer-se como garantia do social, como já fizera saber Maquiavel. A ruptura com o fundamento transcendente leva à figura da imanência, isto é, à ideia do poder popular ou do poder social como origem do poder político. Todavia, isso não basta para alcançar a gênese da democracia moderna tal como Lefort a concebe porque a identificação da democracia com o poder popular, entendido como poder único de todo o "povo", torna invisível a divisão social entre dominantes e dominados e não pode dar conta do verdadeiro significado do poder democrático como lugar vazio.

Com efeito, a desincorporação do poder significa a distinção entre o lugar do poder e o exercício da autoridade. Em outras palavras, o lugar do poder não somente não se identifica com o ocupante do governo, mas também não é consubstancial a nenhuma classe ou grupo social. No entanto, a não identificação do poder com uma classe social, um grupo ou indivíduo não é suficiente para compreendermos o poder democrático. De fato, cada um e todos podem dizer que o poder não pertence a ninguém, entretanto, o essencial é que ninguém pode enunciar que se trata de um lugar važio porque esse vazio indica a impossibilidade de uma determinação positiva ou a impossibilidade de representar a substancialidade de uma comunidade una e indivisa (o "povo"). Vaz̧io não significa inocupado e sim originaria e ontologicamente cindido. Em outras palavras, não é vazio porque ninguém pode ocupá-lo, mas ao contrário, ninguém pode ocupá-lo porque é vazio, cindido, dividido, dessubstancializado e por isso sua ocupação é impossível. ${ }^{6}$ É isto a desincorporação do poder.

Talvez a compreensão dessa enigmática ideia lefortiana do lugar vazio possa ser melhor alcançada se nos lembrarmos de que Lefort se refere à sociedade capitalista como sociedade da alienação ${ }^{7}$ : produzindo a separação de todas as esferas da atividade social e fragmentando cada uma delas, a sociedade torna impossível sua identificação consigo mesma, de sorte que nela o universal não se realiza pela mediação do particular, mas contra ele. A alienação constitutiva da sociedade capitalista nos ajuda a compreender o que se

\footnotetext{
${ }^{5}$ Como no adágio "pelo povo, com o povo e para o povo".

${ }^{6}$ Compreendemos, assim, porque Lefort não pode aceitar a ideia merleaupontyana da Carne como ser de indivisão que, sem cindir-se, se auto-diferencia numa pluralidade inesgotável de dimensões que lhe são imanentes, reversíveis ou em quiasma.

${ }^{7}$ LEFORT, C. As formas da história. São Paulo: Brasiliense, 1979.
} 
passa com o Estado como pretensão de ocupação do lugar do poder. Pretendendo figurar o universal (mas sendo realmente particular), pretendendo ordenar e regular o espaço social para homogeneizá-lo (mas sendo realmente um polo a mais de heterogeneidade), pretendendo oferecer-se como lugar da identificação social (mas sendo realmente uma expressão política da divisão social), pretendendo ser o ponto de confluência da legalidade e da legitimidade (mas sendo realmente o substituto da soberania), pretendendo representar objetivamente os interesses subjetivos da comunidade nacional (mas sendo realmente um momento necessário da exploração econômica), o Estado é a forma superior da alienação na sociedade capitalista. Como autoridade separada não pode efetuar a universalidade do poder senão fixando-se na particularidade (de classe) e, como polo da identificação social, não pode efetuar a generalidade da vida coletiva senão oferecendo-se como potência de dominação. À distância do Estado, instituindo-se a partir de uma divisão originária que não pode ser suprimida - a cisão entre o desejo dos grandes de comandar e oprimir e o desejo do povo de não ser comandado nem oprimido, ou seja, a divisão entre desejo de dominação e desejo de liberdade - a democracia moderna expõe de maneira nova a luta de classes como luta política, isto é, como ação interminável para ocupar o lugar do poder e da ideologia como operação interminável para determinar, delimitar e certificar a legitimidade da dominação, oferecendo o aparecer da sociedade como o ser do social.

Assim, a política democrática só se deixa apanhar quando compreendemos que o ser do político abre uma dialética na qual a posição de um desejo (o dos grandes) se efetua pela sua negação (o desejo do povo) e a efetuação da negação desta negação põe a indivisão como síntese impossível: a dialética do político não desemboca na determinação e sim num excesso - o desejo de indivisão, isto é, de ocupação do lugar do poder - marcando a democracia com o selo da indeterminação, isto é, de uma dialética sem telos e sem síntese pacificadora. É isto a indeterminação democrática, à qual se contrapõem a determinação estatal e a ideológica.

L'essentiel, à mes yeux, est que la démocratie s'institue et se maintient dans la dissolution des repères de la certitude. Elle inaugure une histoire dans laquelle les hommes font l'épreuve d'une indétermination dernière, quant au fondement du Pouvoir, de la Loi et du Savoir, et du fondement de la relation de l'un avec l'autre, sur tous les registres de la vie sociale (partout où la division s'énonçait autrefois, notamment la division entre les détenteurs de l'autorité et ceux qui leur étaient assujettis, en fonction de croyances en une nature des choses ou en un principe surnaturel). C'est ce qui m'incite à juger que se déploie dans la pratique sociale, à l'insu des acteurs, une interrogation dont nul ne saurait détenir la réponse et à laquelle le travail de 
l'idéologie, vouée toujours à restituer de la certitude, ne parvient pas à mettre un terme. ${ }^{8 *}$

Mas não só isso. $\mathrm{O}$ excesso do desejo em direção à indivisão ou à ocupação do lugar do poder e a indeterminação da ação social e política (pois não é sustentada por nenhum fundamento que lhe dê garantias transcendentes) nos fazem compreender o que pretende Lefort ao afirmar que a democracia revela a dimensão simbólica do poder, isto é, que o sentido do poder não se esgota em sua imagem institucional, pois, sendo simbólico, ele exprime a ausência de predeterminação do social a si mesmo e a ausência de um desenvolvimento finalizado ou de síntese, isto é, a ausência de determinação tanto no início quanto no final do percurso.

Talvez possamos compreender o que Lefort designa como simbólico se tomarmos como exemplo a crítica endereçada a Marx, no ensaio sobre a gênese das ideologias na sociedade moderna. Marx parte da divisão sexual do trabalho, isto é, da passagem de uma determinação natural dada para uma determinação posta, isto é, propriamente social. Ora, diz Lefort, a divisão sexual não é um dado primeiro natural porque para ser posta como divisão do trabalho é preciso que ela tenha sido posta como diferença sexual, ou seja, tenha sido simbolizada. ${ }^{9}$

Todavia, para nos acercarmos do que seja o simbólico, o mais adequado é partir da diferença entre ele e o que Lefort nomeia como o real, que, como já dissera Merleau-Ponty, não é fato nem ideia, dado ou representação. Estes são o que aparece em virtude do real, isto é, do trabalho que uma sociedade efetua sobre si mesma para produzir-se e instituir-se, para ocultar-se e fixar-se em máscaras, como se com estas pudesse suspender o tempo e cessar a história. É assim, por exemplo, que é verdade que o liberalismo põe as ideias de igualdade e liberdade, mas é falso que as efetue como ações, pois sua realização desmantelaria a paralisação do tempo pretendida por sua fixação apenas jurídica; porém, simultaneamente,

\footnotetext{
${ }^{8}$ LEFORT, C. "La question de la démocratie", op. cit., p. 29.

* [O essencial, a meu ver, é que a democracia se institui e se mantém na dissolução das referências da certeza. Ela inaugura uma história na qual os homens fazem a prova de uma indeterminação última quanto ao fundamento do Poder, da Lei e do Saber, e do fundamento da relação de um com o outro, sobre todos os registros da vida social (em todo lugar que a divisão outrora se enunciava, notadamente na divisão entre os detentores da autoridade e os que lhes eram sujeitados, em função das crenças numa natureza das coisas ou num princípio sobrenatural). É isto que me incita a julgar que se move na prática social, sem que os autores o saibam, uma interrogação cuja resposta ninguém poderia ter e à qual o trabalho da ideologia, sempre dedicado a restituir a certeza, não chega a pôr fim.] (Tradução dos editores)

${ }^{9}$ Bastaria lembrarmos como, em sociedades em que a menstruação significa a mulher como impura, a divisão sexual do trabalho interdita que as mulheres se ocupem da coleta de alimentos, bem como do plantio e da colheita, assim como do cuidado com os filhos e a casa. Essas tarefas são masculinas, cabendo às mulheres a tarefa da guerra.
} 
ele não pode impedir o trabalho do social para efetuá-las porque essas ideias põem um excesso frente ao que está dado (sem o que não poderíamos compreender a criação de novos direitos a partir de direitos declarados e reconhecidos). Porque o real é o trabalho de instituição do próprio social e de seu mascaramento como instituição permanente, compreende-se que o simbólico é simultaneamente negação do real como fato e afirmação do real como ação dotada de sentido (donde a importância do emprego do conceito de trabalho por Lefort). No entanto, não basta isso. É preciso ainda compreendermos que o simbólico está aberto ao excesso (como vimos acima com as ideias de igualdade e liberdade) e que o excesso do desejo nega a possibilidade da transparência do social a si mesmo e, simultaneamente, a afirma, buscando-a por meio da ilusão da limitação de si mesmo ou de sua determinação, enfim conseguida, pela ocupação do lugar do poder e pela imagem da sociedade como comunidade orgânica, indivisa e concorde consigo mesma, capaz de dominar sua própria história.

O essencial - que chamo de concepção trágica da política - é que a própria dimensão simbólica do poder põe seu negativo na figuração imaginária do poder como unificação de todos os desejos - seja como poder institucional e ideológico da classe dominante, seja como sua realização num governo popular. Não se trata de uma operação malévola que desfigura o poder e sim o desejo excessivo de lhe atribuir a transubstanciação da divisão social numa unidade impossível. ${ }^{10}$

Mas não só isso. Somente a democracia evidencia a divisão entre dominação e liberdade sendo por isso a única formação política que considera o conflito legítimo, não o oculta, mas se abre ao seu trabalho temporal, cabendo indagar em que momento e sob que condições o conflito transborda de si mesmo e se transforma em desordem (o tumulto) e desta passa à luta, isto é, da lógica do conflito passa à lógica da força, seja como violência revolucionária - ou, como explica Lefort, quando o Baixo da sociedade não reconhece a legitimidade do Alto e se põe a derrubá-lo -, seja como tirania, isto é, numa nova incorporação do poder.

Mas também não só isso. A dialética do desejo positivo dos grandes e do desejo negativo do povo se efetua na maneira como a recusa do comando e da opressão abre a ação para a ideia e a prática de instituição de direitos e como criação ininterrupta de novos direitos, abrindo o tempo pela criação do novo e da diferença temporal que ele acarreta. Essa dupla abertura temporal, isto é, ou pela desordem (ou pela revolução) ou pela

\footnotetext{
${ }^{10}$ Penso que se não compreendermos isto não compreenderemos por que Lefort situa o totalitarismo como efeito da indeterminação democrática.
} 
instituição de direitos, explica por que Lefort afirma que a sociedade democrática é a única verdadeiramente histórica, isto é, produz dentro de si mesma a diferença temporal. ${ }^{11}$

\section{Obstáculos à democracia no Brasil}

Situo as dificuldades para a instituição de uma sociedade democrática no Brasil em dois obstáculos principais: de um lado, a forma da sociedade instituída pela materialidade da divisão social polarizada entre os privilégios dos grandes e as carências do povo; de outro, a matriz teológica do modo de aparição da política através da figura do Estado, portanto da figuração institucional do poder. Estes dois obstáculos são o solo no qual estão fincadas as raízes do populismo.

No que concerne à polarização social, isto é, à formação social oligárquica, o privilégio dos grandes (ter mais bens e mais poder) é, por definição, sempre particular, não podendo generalizar-se num interesse comum nem se universalizar num direito porque deixaria de ser privilégio. Por seu turno, as carências populares também são sempre específicas e particulares, não conseguindo, enquanto carências, ultrapassar a especificidade e a particularidade rumo a um interesse comum nem se universalizar num direito. Assim, a divisão social sob a forma da desigualdade em todas as esferas da vida social determina a violência com que os grandes, temerosos do povo, sufocam e reprimem todas as manifestações populares por direitos.

No que concerne à matriz teológica do modo de instituição e aparição da política no Brasil, refiro-me à maneira como o Estado é percebido pela sociedade. De fato, no Brasil, o Estado sempre foi visto como anterior à sociedade, pois, no período colonial, a existência legal da Colônia dependia de ordenações do Estado metropolitano, que era anterior e exterior a ela e a instituía. Seria de supor que essa imagem do Estado desaparecesse com a Proclamação da República. Mas não foi o caso. Embora a Proclamação tenha sido antecedida e sucedida por afirmações de vários partidos políticos como um acontecimento que correspondia aos anseios da sociedade ou que se opunha a eles, tanto liberais como conservadores viram na Proclamação apenas uma reforma do Estado realizada pelo próprio Estado. Assim, embora, de fato, a República exprimisse a realidade concreta das lutas sociais e econômicas e os rearranjos de poder no interior da classe dominante, no entanto, não era assim que ela aparecia e era concebida, uma vez que não aparecia como instituição do Estado pelas lutas sociais e sim como reforma do Estado feita pelo próprio Estado e, portanto, como instituidor do próprio social. Disso resultou a

\footnotetext{
${ }^{11}$ É interessante observar que reencontramos aqui a afirmação de Marx, nos Grundrisse, de que, ao contrário das outras formações econômicas, cujas transformações e dissolução dependem de ações vindas do exterior, somente no modo de produção capitalista a história é interna ou imanente.
} 
imagem do Estado como o único sujeito histórico, ou seja, as mudanças histórico-políticas são vistas como obra do próprio Estado e as mudanças sociais, como produzidas pelo Estado.

Diante disso, cabe perguntar: se não são as lutas sociais que instituem o Estado, qual é a origem do poder estatal? Para responder, precisamos levar em conta que a cultura política brasileira, desde o período colonial, consagrou a concepção teológica do poder, vigente na Península Ibérica, e que, com várias modificações, se conserva até hoje entre nós. Nessa concepção, afirma-se que, pelo pecado, o homem perdeu todos os direitos e, portanto, o direito ao poder, o qual pertence exclusivamente a Deus, pois, como lemos na Bíblia: "Todo poder vem do Alto \Por mim reinam os reis e governam os príncipes". É por uma decisão misteriosa e incompreensível que o Alto transcendente concede o poder, ou seja, é por uma graça especial que Deus concede poder a alguns homens. A origem do poder humano é, assim, um favor divino àquele que $\mathrm{O}$ representa, ou seja, o governante não representa os governados, mas a fonte transcendente do poder, Deus. Isto significa também que governar é realizar ou distribuir favores (imitação da graça divina): o Alto (o governante) concede aos governados (o Baixo) direitos por meio de decretos e leis. O governante foi escolhido por Deus para ser o pastor do rebanho divino e dele cuidar como um pai severo e amoroso. Isso se vê claramente na política brasileira, antiga e contemporânea, ou seja, os representantes não se consideram portadores de um mandato que lhes foi conferido pelos representados, mas se veem como representantes do poder estatal e mantêm com os representados a relação do favor ou da clientela. Por um favor divino, o governante é dotado de vontade absoluta, donde o adágio: "o que apraz ao rei, tem força de lei”. Desta maneira, o governante por favor divino é despótico, no sentido etimológico e político do termo: a república se torna família, o fundo público se torna patrimônio privado, a lei exprime a vontade pessoal do governante e a ação política se realiza sob a forma da relação direta, sem mediação, entre o doador de favores e a clientela. No caso do Brasil, a expressão cunhada por Raimundo Faoro é cristalina: "os donos do poder", indicando que o Estado brasileiro é patrimonialista, ou seja, o território da nação é patrimônio da classe dominante brasileira, pois nossa formação social é oligárquica.

A matriz teológica explica não só porque o Estado aparece como uma força distinta e separada da sociedade, ou seja, como um poder que sobrevoa a sociedade e que tudo pode ao intervir sobre o social, mas também explica a tendência popular de relacionar-se com o governante de maneira sacralizada, isto é, ou como um salvador ou como um demônio. Assim, no imaginário político brasileiro de ontem e de hoje, há a figura de um poder que se forma no Alto, se desenvolve no Alto e dirige do Alto a sociedade em seus mínimos detalhes. 
A polarização material (econômica, jurídica, cultural) entre privilégio e carência e a matriz teológica (política) constituem uma formação social que está pronta para a instituição do populismo.

Não vou tomar o populismo como sinônimo de coronelismo ou de caudilhismo, à maneira do que se passou com Vargas e o Estado Novo como um compromisso entre forças agrárias e industriais, graças ao controle da classe trabalhadora pela Legislação Trabalhista. Essa caracterização perdeu força porque, desde os anos 1950, tornou-se evidente que um líder populista pode apresentar-se com características da ideologia urbana, isto é, tanto como aquele que se dirige à classe média prometendo-lhe o fim da corrupção política e dos costumes (como Jânio Quadros e Fernando Collor) quanto sob a forma do administrador competente (como Paulo Maluf). Em outras palavras, a urbanização, a industrialização e os serviços fazem com que novas personagens possam ser líderes populistas não apresentando os antigos traços do caudilho ou do coronel, isto é, das formações oligárquicas agrárias.

Caracterizo o populismo brasileiro com os seguintes traços:

1. um poder que se realiza sem as mediações políticas, isto é, que opera ativamente para afastar as instituições políticas, tanto os partidos políticos, como formas políticas de organização da sociedade civil, quanto a própria estrutura de organização do Estado, sob a forma mediada dos três poderes republicanos. Pretende operar numa relação direta entre o governante e os governados.

2. um poder pensado e realizado sob a forma da tutela e do favor, em que o governante se apresenta como aquele que detém não só o poder, mas também o saber sobre o social e sobre a lei e, portanto, priva os governados do conhecimento do mundo sócio-político, podendo, assim, tutelá-los; traço que, contemporaneamente, se exprime no que denomino a ideologia da competência.

3. um poder que opera simultaneamente com a transcendência e a imanência, isto é, o governante se apresenta como transcendendo o social, na medida em que é o detentor do poder, do saber e da lei; mas, ao mesmo tempo, só consegue realizar sua ação se também fizer parte do todo social, já que não opera com mediações institucionais. Donde sua posição ambígua de transcender o social e, no entanto, ser imanente a ele.

4. um poder incorporado, isto é, a indistinção entre o poder e aquele que exerce a função de governo. No populismo, o poder encontra-se total e plenamente ocupado pelo governante que encarna e incorpora o poder, o qual não mais se separa nem se distingue de sua pessoa, uma vez que não se funda em instituições públicas nem se realiza através de mediações sócio-políticas.

5. um poder personalista, isto é, o exercício do poder e a forma do governo oferecem a pessoa privada do governante como sua pessoa pública. 
6. um poder que é uma das formas paradigmáticas de autoritarismo político. ${ }^{12}$

Para compreendermos porque o populismo deita raízes no Brasil, proponho acompanhá-lo a partir do que designo como nosso mito fundador, cujos constituintes são: primeiro, a matriz teológica do poder (a que me referi há pouco); segundo, para usarmos a expressão de Sérgio Buarque de Holanda, a "visão do paraíso", que designarei como a elaboração mítica do "Oriente"; terceiro, a história teológica, construída pela ortodoxia cristã, isto é, a perspectiva providencialista da história; e quarto, a história teológica herética cristã, ou seja, a história profética ou milenarista.

Quando lemos os diários de bordo e a correspondência dos navegantesconquistadores das Américas, bem como a correspondência, os ensaios e livros dos evangelizadores, descobrimos que a palavra Oriente indica algo mais do que um lugar ou uma região. Embora, aparentemente, signifique o Japão, a China e a Índia, na verdade, como as cartas de Colombo, Américo Vespúcio e Pero Vaz de Caminha atestam, Oriente é o Jardim do Éden. A Bíblia, no livro da Gênese, afirma que o paraíso terrestre, terra cortada por quatro rios que atravessam toda a terra, localiza-se no Oriente. A partir do relato bíblico, as grandes profecias, particularmente as de Isaías e Daniel, descreveram com detalhes o oriente-paraíso, terra cortada por rios cujos leitos são de ouro e prata, por onde correm leite e mel, em cujas montanhas derramam-se pedras preciosas, habitado por gentes belas, indômitas, doces e inocentes como no Dia da Criação, promessa de felicidade perene e redenção. Este topos do Oriente como jardim do paraíso pode ser imediatamente percebido na explicação da bandeira do Brasil. Quando se pergunta qual o significado de suas quatro cores responde-se que o verde representa nossas imensas e inigualáveis florestas; o amarelo, a inesgotável riqueza natural do solo pátrio; o azul, a beleza perene de nosso céu estrelado, onde resplandece a imagem do Cruzeiro, sinal de nossa devoção a Cristo Redentor; e o branco, a ordem (com progresso, evidentemente). A bandeira brasileira é um símbolo da natureza: floresta, ouro, céu, estrelas e ordem.

A produção mítica do país-jardim nos lança no reino da Natureza e fora do mundo da História. E, como se trata da natureza-paraíso, estamos no mundo da indivisão perfeita, não havendo sequer como falar num estado de natureza de estilo hobbesiano em que a guerra de todos contra todos e o medo da morte suscitariam o social, o pacto e o advento do político. Nesse estado de natureza indiviso e paradisíaco em que nos encontramos, há

\footnotetext{
12 Embora eu esteja propondo traços do populismo brasileiro, talvez seja possível generalizá-los diante do que se passa atualmente (2016-2017) nos Estados Unidos e na Europa, durante as campanhas eleitorais, quando o termo "populismo" ressurgiu para referir-se aos discursos e programas dos candidatos conservadores e os de extrema-direita. Crítica da política enquanto política, recusa das mediações institucionais republicanas, recusa da democracia, personalismo (a figura do indivíduo bem-sucedido por mérito próprio e eficiência nos negócios), salvacionismo com a demonização dos imigrantes e dos movimentos de gênero.
} 
apenas nós - pacíficos e ordeiros - e Deus que, olhando por nós, nos envia um governante que $\mathrm{O}$ represente. Nascemos, portanto, sob o signo da indivisão originária.

O segundo elemento na produção do mito fundador vai lançar-nos na história, depois de nos haver tirado dela. Todavia, trata-se de uma história teológica ou providencialista, isto é, a história como realização do plano de Deus ou da vontade divina. Quem melhor instituiu essa história foi, sem dúvida, Santo Agostinho ao pensá-la como teofania (revelação de Deus no tempo), epifania (revelação da verdade divina no tempo), profecia (cumprimento da vontade de Deus no tempo) e soteriologia (promessa de redenção no tempo). O tempo é ocasião para o cumprimento do plano divino. Com a vinda de Jesus, cumpriu-se a promessa de redenção e terminou o tempo real, restando apenas o tempo empírico de nossas vidas individuais. Como humanos mortais, estamos na eternidade - participando da Igreja, Jerusalém Terrestre - e como humanos dotados de alma imortal, participaremos da eternidade - o Reino de Deus como Jerusalém Celeste. O verdadeiro tempo já transcorreu, restando, agora, a oposição entre o século (tempo profano nulo) e a eternidade (ausência de tempo). Ora, se o Brasil é o paraíso reencontrado, estamos numa história que se realiza sem tempo e fora tempo - "deitado eternamente em berço esplêndido", como canta nosso Hino Nacional. Fazemos parte do plano providencial de Deus, que nos escolheu como um Povo Eleito.

No entanto, contraposta à história providencialista já realizada, existe uma outra. Trata-se da história messiânica milenarista, considerada herética pela ortodoxia cristã. Iniciada nos começos do cristianismo, retomada durante as vésperas do Ano Mil, e reelaborada pelo abade Joaquim de Fiori, no século XII, essa concepção da história será retomada pelos franciscanos e, a seguir, pelos navegantes e pelos jesuítas. Trata-se de uma história fundada no tempo concebido como epifania da Santíssima Trindade. De modo extremamente resumido e empobrecido, podemos assinalar, aqui, os dois traços principais desta história: a divisão do tempo em três eras - do Pai, do Filho e do Espírito, ou da lei, da graça e da sabedoria - e o embate final entre o Anticristo e Cristo, durante a era messiânica, com a vitória de Cristo, que é antecedida pela vitória daquele que prepara o embate final, o Combatente dos Últimos Dias, que aprisionará o demônio durante mil anos de felicidade e abundância, até que Cristo, desenterrando o demônio, vença para sempre o mal.

Enquanto a história providencial é apropriada pela camada dirigente da Igreja e pelos grandes (pois assegura que as instituições existentes são o plano divino realizado), a história milenarista é apropriada pelo povo, isto é, por todos os dissidentes cristãos e pelas classes populares, formando o fundo messiânico de interpretação da vida presente como miséria à espera dos "sinais dos tempos" que anunciarão a chegada do Anticristo e do combatente vitorioso, que prepara o caminho para a Segunda Vinda do Cristo. É com esta matriz que as classes populares têm acesso à política como luta entre o bem e o mal e na 
qual a questão não é a do poder, mas a da justiça e da felicidade [encontramos todas essas ideias em Canudos, no Contestado, em Pedra Bonita]. O pré-salvador surge nas vestes do dirigente em quem são depositadas todas e as últimas esperanças. No Brasil, é esta a figura assumida pelo líder populista perante as camadas populares.

A matriz mítica opera de modo socialmente diferenciado:

- do lado da classe dominante, exprime-se na visão de seu direito natural ao poder e na legitimação desse direito por meio do ufanismo nacionalista e desenvolvimentista, expressões laicizadas do Paraíso Terrestre e da teologia da história providencialista. Em outras palavras, exprime-se na imagem do Brasil como comunidade una e indivisa, ordeira e pacífica, rumando para seu destino, e no modo como institui a política sob a forma da tutela e da clientela populista. O Brasil é "mãe gentil" e o governante, "pai da pátria";

- do lado das classes populares, a matriz mítica se realiza pela via milenarista que, por sua vez, produz dois efeitos principais: a visão do governante como salvador e a sacralização-satanização da política. Em outras palavras, uma visão messiânica da política que possui como parâmetro o núcleo milenarista como embate cósmico final entre a luz e a treva, o bem e o mal, de sorte que o governante ou é sacralizado (luz e bem) ou satanizado (treva e mal).

Tanto num caso como noutro, a matriz mítica exprime o desejo de indivisão, preserva a personalização do poder, impede a operação das mediações, reforça o autoritarismo social e dá origem ao populismo político como barreira contra a indeterminação democrática, isto é, fecha o tempo histórico.

Poder-se-ia argumentar que o "desencantamento do mundo" e a laicização moderna da política teriam abolido a teologia política e, com ela, a matriz mítica cujos traços gerais acabei de traçar. Ora, essa matriz constrói a figura da transcendência do poder, porque originado de uma determinação extrassocial que lhe daria um fundamento seguro para conservar-se, sendo por isso periodicamente refeita com noções que correspondem ao presente histórico, ou seja, a mitologia é conservada por intermédio das ideologias. É assim que, por exemplo, as ideologias nacionalistas reforçam a imagem do Paraíso, enquanto as ideologias desenvolvimentistas reforçam a história providencialista; as ideologias autoritárias reforçam a imagem do poder encarnado no governante, enquanto as ideologias vanguardistas reforçam a história milenarista. Em outras palavras, a mudança temporal das ideologias, em consonância com seu presente social, se realiza sobre o fundo silencioso, invisível e perene da mitologia, ocultada por discursos laicos. Por isso se trata de um mito fundador, pois, como toda fundatio, liga o presente a um passado que não cessa jamais.

As ideologias, por seu turno, encontram uma base material real para se constituírem como expressões imaginárias da sociedade brasileira: o autoritarismo social. De fato, a estrutura e organização da formação social brasileira reiteram, alimentam e repetem a mitologia porque nesta vem inscrever-se a própria forma de nossa sociedade. O 
autoritarismo, portanto, não é a marca dos governos ou do Estado e sim o modo de ser de nossa formação social, pois a forma de nossa sociedade é autoritária pela maneira como institui as relações sociais como relações de mando e obediência entre um superior e um inferior e que se repetem em todas as esferas da vida social (da família ao Estado, passando pelas relações de trabalho, pela escola, pela cultura). Vivemos numa sociedade verticalizada e hierarquizada (embora não o percebamos) na qual as relações sociais são sempre realizadas ou sob a forma da cumplicidade (quando os sujeitos sociais se reconhecem como iguais), ou sob a forma do mando e da obediência entre um superior e um inferior (quando os sujeitos sociais são percebidos como diferentes, a diferença não sendo vista como assimetria, mas como desigualdade) e da repressão violenta (quando a desigualdade é profunda). Essas formas da relação social são ocultadas por aquilo mesmo que as realiza e as conserva: as relações de favor, tutela e clientela. Numa palavra, não existe cidadania.

A estrutura autoritária de nossa formação social bloqueia o trabalho da desincorporação do poder, definidor da democracia. Ora, se a democracia, como desincorporação do poder, é a condição para suplantar a teologia política, não temos como suplantá-la e não podemos senão repetir, sob aparências laicas variadas, o populismo. Com efeito, a carência (popular) espera ser preenchida e suprida pelo governante tutelar; o privilégio (dominante) espera ser conservado pelos favores do governante, que foi eleito pelos favores dos dominantes. A esfera pública não consegue constituir-se, a distinção entre público e privado não consegue instituir-se, as mediações sociais e políticas não conseguem firmar-se.

Eis porque o neoliberalismo nos cai como uma luva, pois opera com o encolhimento do espaço público e o alargamento do espaço privado. A ideologia neoliberal alimenta tudo aquilo que está presente na matriz teológica do poder, isto é, a noção de personalidade e subjetividade como centro do poder, a indiferenciação entre público e privado, o narcisismo do governante, a política como espetáculo, mistério, transcendência e saber acessível somente aos iniciados, os competentes. O neoliberalismo transforma a política em espetáculo e simulacro e, deste ponto de vista, repõe, com outros meios e aparências, a liturgia teológica do poder.

Mas não só isso. Se assim opera a ideologia neoliberal, também precisamos considerar o modo de operação da economia neoliberal, isto é, a fragmentação e dispersão da produção econômica (incidindo diretamente sobre a classe trabalhadora, que perde seus referenciais de identidade, de organização e de luta), a rotatividade extrema da mão de obra, a obsolescência vertiginosa das qualificações para o trabalho em decorrência do surgimento incessante de novas tecnologias e o desemprego estrutural, decorrente da automação e da alta rotatividade da mão de obra, produzindo todas as formas de exclusão. A perda de referenciais sociais e o sentimento de humilhação, opressão e injustiça podem suscitar a busca de uma saída na qual a invocação religiosa, por sua simplicidade e proximidade, surja 
como caminho de conquista da justiça. Ora, sabemos que a visão milenarista-messiânica tende a crescer e a fortalecer-se toda vez que as classes populares estão despojadas de referenciais propriamente sociais que lhes permitam perceberem-se como sujeitos políticos e históricos, vendo-se a si mesmas como massa desagregada à procura de um sentido que se exprime como luta entre a treva e a luz, e que anseia pela figura salvífica do bom governante.

Uma vez que o autoritarismo social efetua a divisão social como relação entre o Alto e o Baixo da sociedade, não podemos supor que a referência à matriz mítica do populismo teria perdido sentido a partir do final dos anos 1980 e durante os anos 1990, décadas em que os temas centrais da política brasileira eram a democratização e a modernização do país. Ora, a primeira, conduzida sob a batuta do General Golbery do Couto e Silva (que legou um sistema político-partidário forjado nos estertores da ditadura e conservado até hoje) foi denominada Conciliação pelo Alto, isto é, uma nova articulação entre o Estado e as exigências da classe dominante. Não nos poderia surpreender, portanto, que, eleito indiretamente pelo Colégio Eleitoral, Tancredo Neves tenha pronunciado um discurso em que identificava o presidente da república com a figura bíblica do Bom Pastor. Por seu turno, a modernização foi entendida como passagem do modelo econômico desenvolvimentista (que se esgotara com o "milagre brasileiro") à adoção do neoliberalismo, que se legitima pela ideologia da competência técnico-administrativa e do espaço público como manifestação narcísica da figura do governante (seus gostos e preferências sexuais, esportivas, culinárias e de vestuário, seus familiares, seus hobbies e bichos de estimação). Ora, aqui também não nos poderia surpreender que a campanha eleitoral de Fernando Collor operasse com duas imagens aparentemente excludentes: de um lado, um trem-bala que avançava quase na velocidade da luz em direção ao moderno, dominado pela competência técnico-administrativa do governante; e, de outro, sua chegada aos comícios, à noite, num helicóptero, num show de luz e som que antecedia sua descida, literalmente, do Alto. Tanto no caso de Tancredo quanto no de Collor não se tratava apenas de uma figuração que mesclava o antigo e o moderno e sim da reiteração (no caso do primeiro, pela prática da conciliação e, no do segundo, pela afirmação da competência e de sua aparência física) da forma populista naquilo que possui de mais persuasivo para a tradição política brasileira: o poder do Alto, isto é, o Estado como sujeito político e histórico.

\section{A mudança possível}

Brizola: Precisamos fazer como Cristo e distribuir os peixes ao povo.

Lula: Acho melhor que o povo decida pescar.

Diálogo entre Brizola e Lula durante o último comício pelas Diretas-Já 
Em 1976, um grupo de intelectuais, vindos de diversas tendências de esquerda, de representantes do novo sindicalismo e de movimentos sociais, que começavam a constituirse, reuniu-se em um centro de estudos com a intenção de refletir sobre o Brasil, afastando duas perspectivas predominantes na esquerda brasileira da época: a da teoria da dependência e a ideia da política como ação de uma vanguarda. A primeira assentara sua interpretação do Brasil (e dos países chamados dependentes) sobre um tripé em que o Estado, o capital nacional e o capital internacional eram os protagonistas sociais, políticos e históricos, portanto, no qual estavam ausentes a classe trabalhadora e as camadas populares em geral. Em outras palavras, o tripé pensava a política e a história como ação do Alto. Por seu turno, a concepção vanguardista (presente de formas variadas nas múltiplas tendências de esquerda) fundava-se, de um lado, numa ideia pedagógica da política como educação das massas por um partido que tomaria o Estado e, de outro, na de direção política das massas por uma vanguarda, portadora da consciência de si e para si, capaz de decifrar o sentido da história. Novamente, a política e a história se fariam pelo Alto.

O novo centro de estudos, denominado CEDEC (Centro de Estudos de Cultura Contemporânea), apresentou-se publicamente da seguinte maneira:

(...) cujo objetivo principal consiste na consolidação de um espaço para a realização de pesquisas e debates sobre aspectos sociais, políticos, econômicos e culturais da realidade brasileira, com ênfase especial na problemática das classes populares. Nesse sentido, dirige suas atividades para as seguintes áreas: movimento operário e sindical, trabalhadores rurais, movimentos sociais urbanos, cultura popular, violência e marginalidade, Igreja em suas relações com os movimentos populares, ideologia e partidos políticos. ${ }^{13}$

Como se observa, agora a referência é a sociedade, tomada como ação daqueles que Eder Sader denominou "novos sujeitos políticos" ou "um novo sujeito coletivo", isto é, o Baixo em conflito com o Alto. Hoje, isso parece uma obviedade ululante e ninguém se espanta com o papel desses novos sujeitos na sociedade brasileira. Nos anos 1970, porém, essa perspectiva, rompendo com nossas tradições intelectuais e políticas, pode ser considerada profundamente inovadora, afirmando, pela primeira vez no pensamento brasileiro, que o social existe, que está dividido e tem força instituinte.

Evidentemente, o CEDEC não surgiu do nada nem da cabeça de alguns intelectuais como Minerva da cabeça de Júpiter. Pelo contrário, o que o tornou possível foi a existência

${ }^{13}$ CEDEC/Documentação 1, maio de 1980, p. 3. 
da ação social como resistência à ditadura, como luta pela liberdade e, por isso mesmo, contra a polarização entre a carência e o privilégio, ação realizada pelo movimento sindical ou o novo sindicalismo, pelos movimentos sociais urbanos e rurais, pelas Comunidades Eclesiais de Base, inspiradas na Teologia da Libertação, pelos movimentos estudantis contra a ditadura, pelo grupo Tortura Nunca Mais, instituído pelas famílias de presos e desaparecidos políticos sob a proteção da Comissão de Justiça e Paz. Dessas ações nasceram as comissões de fábricas com a conquista do direito de greve e a organização independente dos trabalhadores, os loteamentos clandestinos nas cidades e as ocupações no campo como início da reforma agrária, os movimentos contra o custo de vida, por transporte, creches, escolas e hospitais, pela urbanização das favelas, contra o racismo e as discriminações de gênero, contra a tortura e o desaparecimento de presos políticos, contra os assassinatos de lideranças populares pelas forças policiais e pelo Esquadrão da Morte.

Escrevendo sobre esses acontecimentos, Eder Sader considerou que se tratava do surgimento de um novo sujeito político no Brasil:

Este texto é produto de uma pesquisa e de uma reflexão sobre novas configurações sociais assumidas pelos trabalhadores da Grande São Paulo no curso da década de 70. Isso que estou chamando de "novas configurações dos trabalhadores" não consiste num fenômeno extensivo ao conjunto dessa classe, mas, antes, a uma parcela, que constituiu movimentos sociais, com novos padrões de ação coletiva, que nos permitem falar da emergência de novos sujeitos políticos. Considerando que essa emergência abre um novo período na história das classes trabalhadoras em nosso país, eu me propus a investigar circunstâncias e características dessa nova configuração. ${ }^{14}$

Poderíamos indagar: por que sujeito político novo?

Antes de mais nada, porque criado pelos próprios movimentos sociais populares do período: sua prática os põe como sujeitos sem que teorias prévias os houvessem constituído ou designado. Em segundo, porque se trata de um sujeito coletivo e descentralizado, portanto despojado das duas marcas que caracterizaram o advento da ideologia burguesa da subjetividade: a individualidade solipsista ou monádica como centro de onde partem ações livres e responsáveis e o sujeito como consciência individual soberana de onde irradiam ideias e representações, postas como objetos domináveis pelo entendimento. O novo sujeito é social: são movimentos sociais populares em cujo interior

${ }^{14}$ SADER, Eder. Quando novos personagens entraram em cena. Experiências, falas e lutas dos trabalhadores da Grande São Paulo (1970-1980). Rio de Janeiro: Paz e Terra, 1988. 
indivíduos, até então dispersos e privatizados, passam a definir-se, reconhecer-se mutuamente, decidir e agir em conjunto e a redefinir-se a cada efeito resultante das decisões e atividades realizadas. Em terceiro legar, porque é um sujeito que, embora coletivo, não se apresenta como portador da universalidade definida a partir de uma organização determinada que operaria como centro, vetor e telos das ações sócio-políticas e para a qual não haveria propriamente sujeitos, mas objetos ou engrenagens da máquina organizadora. Referido à Igreja, ao sindicato e às esquerdas, o novo sujeito neles não encontra o antigo centro, pois são, como explica Sader, instituições nas quais houve um descolamento com seus destinatários respectivos e estão em busca de vias para reatar relações com eles. Assim, do lado da Igreja, o recurso à Teologia da Libertação; do lado das esquerdas, o esforço para reformular o discurso marxista; do lado do sindicalismo, a busca de um discurso e de uma prática para os quais não existia uma tradição nem sistematicidade, mas que visava ao novo ao alargar a compreensão dos conflitos e contradições da sociedade de classes pelo alargamento do espaço fabril como campo de solidariedade, aprendizado da luta de classes e busca de autonomia por meio das comissões de fábrica. A Teologia da Libertação introduz o discurso da "conscientização"; as esquerdas, o da "reflexão crítica"; e o novo sindicalismo, o da "socialização do saber". Novo, finalmente e sobretudo, porque esses sujeitos defendiam a autonomia de suas ações, rompendo com a tradição sócio-política brasileira de tutela e cooptação, criando por isso novos lugares de exercício da política nos quais a política institucional ainda não lançara seus tentáculos: o cotidiano popular.

Descrevendo as ações, nascidas do cotidiano popular e das práticas do novo sindicalismo, que rumavam para a instituição da cidadania, Silvio Caccia Bava assim as sintetiza:

- organizaram-se a partir da iniciativa da própria população, independentes do Estado e dos partidos políticos;

- ganharam importância porque conseguiram a ampla participação da população, constituindo-se como movimento de massa;

- garantiram a ampla participação da população graças à democracia interna, que permitiu a todos participar do processo de decisões que encaminhava as lutas;

- ao apresentarem suas reivindicações, permaneceram organizados e pressionando o poder público, sem confiarem que as autoridades atenderiam seus pedidos sem pressão popular;

- buscavam a unificação dos movimentos através de propostas de luta conjunta e não de entendimentos de cúpula; 
- souberam desafiar as leis e as ameaças vindas de cima, confiando em que a única maneira de enfrentar suas necessidades era assumindo a luta por seus direitos com suas próprias mãos, com a força de sua união. ${ }^{15}$

Luta por direitos, recusa de favores e tutela, democracia direta e participativa, intervenção no espaço público pelo enfrentamento com os poderes constituídos e pela transgressão dos limites impostos por uma legalidade considerada ilegítima, combate aos preconceitos de classe, étnicos, religiosos e de gênero, essas ações contra a dominação enunciaram a si mesmas numa expressão lapidar proferida por um trabalhador: "lutamos por nossa dignidade".

Enraizado nas lutas pela dignidade do Baixo, nasceu um partido político de esquerda novo no Brasil. Novamente, podemos indagar: por que novo? Porque, até então, os partidos de esquerda se constituíam a partir da classe média urbana e dos estratos inferiores das Forças Armadas, apresentando-se como partidos para os trabalhadores. Agora, porém, surgia um partido dos trabalhadores como sujeitos de sua própria ação.

Essas breves e muito sumárias considerações sobre a história social e política recente do Brasil tiveram como intuito assinalar a possibilidade de ruptura com a tradição populista e oferecer algumas chaves para compreendermos porque os governos de Lula não podem ser definidos pelo populismo.

Evidentemente, nosso primeiro impulso seria dizer que Lula não é populista porque não preenche a primeira exigência do populismo, isto é, ser membro da classe dominante. Isto, porém, em si mesmo, não quer dizer muita coisa. O que o afasta do populismo é ser ele uma expressão exemplar do que narramos acima, isto é, da construção social da cidadania e, portanto, da criação do espaço público propriamente dito. Em segundo lugar, porque seus governos operaram com as mediações institucionais do espaço público republicano e impediram sua privatização tanto na forma populista quanto neoliberal, buscando concretizar os princípios republicanos da Constituição de 1988 (particularmente a autonomia do poder legislativo e do poder judiciário). Em terceiro, porque esses governos, por meio das Conferências Nacionais, deram força aos princípios democráticos da Constituição de 1988, realizando-se como campo aberto à participação política dos movimentos sociais e populares pela criação de novos direitos - as Conferências não operaram com demandas nem se dirigiram a favores, e sim, de um lado, como um contrapoder social e, de outro, como apresentação e defesa de diretrizes políticas e de programas de ações afirmativas postas pelos próprios sujeitos políticos. Em quarto lugar, porque dessa maneira, esses governos operaram assegurando a emergência e $O$ fortalecimento da cidadania para que os próprios cidadãos criassem direitos, afastando,

${ }^{15}$ BAVA, Silvio Caccia. “Os conselhos populares”. Desvios, n. 2, 1983, p. 93. 
assim, o centro definidor da sociedade brasileira, isto é, a divisão social como polarização entre carência e privilégio, polarização que, como procurei mostrar, é o pressuposto necessário do populismo e que, nos anos 1990, foi a mola propulsora para a adoção dos princípios econômicos e políticos do neoliberalismo, encolhendo o espaço público e alargando o espaço privado.

Lefort buscou na indeterminação constitutiva da democracia as raízes do totalitarismo. Eu gostaria de retomar essa indeterminação para nela encontrar a possibilidade do ressurgimento do populismo no Brasil.

Neste momento, podemos observar que, mais uma vez, reaparece no país o imaginário da crise. De fato, faz parte de nossa história política e ideológica a maneira como a classe dominante, toda vez que se sente ameaçada em seus privilégios, produz a imagem da crise institucional e dos costumes como perigo, caos e insegurança. A crise, apontando seus agentes, desnudaria o insuportável que deve ser combatido a todo custo: a divisão social.

Por que a produção ideológica da imagem da crise pode ter eficácia política? Deixo a palavra a Lefort:

Dans une société où les fondements de l'ordre politique et de l'ordre social se dérobent, où l'acquis ne porte jamais le sceau de la pleine légitimité, où la différence des statuts cesse d'être irrécusable, où le droit s'avère suspendu au discours qui l'énonce, où le pouvoir s'exerce dans la dépendance du conflit, la possibilité d'un dérèglement de la logique démocratique reste ouverte. Quand l'insécurité des individus s'accroit, en conséquence d'une crise économique, ou des ravages d'une guerre, quand le conflit entre les classes et les groupes s'exaspère et ne trouve plus sa résolution symbolique dans la sphère politique, quand le pouvoir paraît déchoir au plan du réel, en vient à apparaitre comme quelque chose de particulier au service des intérêts et des appétits de vulgaires ambitieux, bref se montre dans la société, et que du même coup celle-ci se fait voir comme morcelée, alors se développe le phantasme du peuple-un, la quête d'une identité substantielle, d'un corps social soudé à sa tête, d'un pouvoir incarnateur, d'un État delivré de la division. ${ }^{16 *}$

\footnotetext{
${ }^{16}$ LEFORT, C. "La question de la démocratie", op. cit., p. 29.

* [Numa sociedade em que os fundamentos da ordem política e da ordem social desaparecem, em que o adquirido nunca porta o selo da plena legitimidade, em que a diferença dos status deixa de ser irrecusável, em que se prova suspenso o direito do discurso que o enuncia, em que o poder se exerce na dependência do conflito, a possibilidade de um desregramento da lógica democrática permanece aberta. Quando a insegurança dos indivíduos aumenta em consequência de uma crise econômica, ou da devastação de uma guerra, quando
} 
Forjada pelos meios de comunicação de massa e pelas oposições políticas, a atual figura da crise exaspera o conflito entre as classes e os grupos e, incitando o ódio e o medo sociais, se apresenta como exigência da restauração da ordem e da segurança ao exigir "un corps social soudé à sa tête"* e "un État delivré de la division"**, instigando, portanto, (sem nunca dizê-lo explicitamente) a demanda social por um poder populista, dirigida tanto à classe média urbana quanto às classes populares das periferias das cidades.

Como lembra Moses Finley, em Democracia antiga e moderna, um fenômeno paradoxal percorre a ciência política contemporânea, qual seja, a tese de que o sucesso das democracias modernas tem como causa a apatia política dos cidadãos, que delegam a técnicos e a políticos profissionais as decisões concernentes à existência social no seu todo. Com efeito, os defensores da apatia e da necessidade de elites dirigentes afirmam que o maior perigo para a democracia é a intervenção política da "massa dos descontentes", que redunda em "movimentos populares extremistas". Ora, lembra Finley, todo historiador sabe que os extremismos que golpearam mais duramente a democracia nunca vieram dos movimentos populares e sim de oligarquias poderosas, convencidas de que não obteriam seus fins por meios democráticos.

Por mais alucinante que seja a operação em curso no Brasil, em que a imagem da crise põe em cena o perigo do comunismo (!), ela encontra eco na classe média urbana que, ciosa de privilégios, que imagina perder com o avanço das políticas de transferência de renda, e preocupada com a preservação de valores morais conservadores, assume como seu o desejo dos grandes e demanda um líder populista do tipo de Jânio Quadros. Do lado popular, com a presença avassaladora das religiões evangélicas, que são teologicamente messiânicas, há estímulo ao apelo à figura de um líder carismático salvador. A classe dominante dispõe de personagens para um retorno do populismo: Aécio, o bom menino bem-nascido, cujo avô identificara a figura do presidente da república com a figura bíblica do Pastor do Rebanho, e Alckmin, homem da Opus Dei, respondem ao anseio populista da classe média urbana; Eduardo Cunha (ou alguém que ocupe seu lugar), homem das igrejas evangélicas, responde ao anseio populista do messianismo popular.

o conflito entre as classes e os grupos se exaspera e não encontra mais resolução simbólica na esfera política, quando o poder parece falhar no plano da realidade, e vem a aparecer como algo de particular a serviço dos interesses e dos apetites de ambiciosos vulgares, em suma se mostra na sociedade, e que ao mesmo tempo esta se faz ver como cindida, então se desenvolve o fantasma do povo-um, a busca de uma identidade substancial, de um corpo social soldado a sua cabeça, de um poder encarnador, de um Estado libertado da divisão.] (Tradução dos editores)

* "um corpo social soldado a sua cabeça" (Tradução dos editores)

** “um Estado libertado da divisão” (Tradução dos editores) 


\section{Referências bibliográficas}

BAVA, Silvio Caccia. “Os conselhos populares”. Desvios, n. 2, 1983, p. 93.

LEFORT, C. "La question de la démocratie". Essais sur le politique. XIX et XX siècles. Paris: Seuil, 1986.

. As formas da história. São Paulo: Brasiliense, 1979.

SADER, Eder. Quando novos personagens entraram em cena. Experiências, falas e lutas dos trabalhadores da Grande São Paulo (1970-1980). Rio de Janeiro: Paz e Terra, 1988. 